\title{
An Economic Analysis of Brinjal (Solanum melongena L.) Cultivation in Nadia District of West Bengal, India
}

\author{
Mridul Mondal*, Hasrat Ali and Bimal Kumar Bera
}

Department of Agricultural Economics, Bidhan Chandra Krishi Viswavidyalaya, Mohanpur, Nadia, West Bengal, Pin: 741252, India

*Corresponding author

\section{A B S T R A C T}

Keywords

Cost of cultivation, Net return, ReturnCost ratio

Article Info

Accepted:

04 October 2019

Available Online:

10 November 2019
Brinjal, being an important vegetable crop, is grown extensively throughout the country including the state of West Bengal. Study on costs and returns structure reveals that the sample farmers have made an investment of Rs. 164365.65/, Rs. 276502.12/ and Rs. 347758.45/ ha in terms of Cost $A_{1}$, Cost B and Cost $\mathrm{C}$ on an average respectively considering farmers of all size groups to realise a gross return of Rs. $382866.62 / \mathrm{ha}$. The net returns are estimated to be Rs. 218500.97, Rs. 106364.50 and Rs. 35108.17/ha over Cost $\mathrm{A}_{1}$, Cost B and Cost C with the return - cost ratios of 2.33,1.38 and1.10 respectively. Although, farmers belonging to the farm size class of 0.5 to 1.0 ha have spent maximum total cost of Rs. 353342.68/ha to get the maximum net return of Rs. $44120.59 /$ ha with return-cost ratio of 1.12 , but no definite relationship between farm size and net returns can be established from the study. Brinjal cultivation is not only economically profitable, but also highly labour intensive requiring 688 man-days during the complete production process which provides ample scope for employment of rural people.

\section{Introduction}

Horticulture sector provides excellent opportunities in raising the income of the farmers even resulting a sustainable increase in production and productivity of vegetable crops throughout the country. China has a 60.67 per cent share of world production, while India's share stands at 25.70 per cent
(Meherunnahar and Paul, 2012). In West Bengal also, the area under horticultural crops is growing rapidly replacing the traditional crops to meet the increased demand arising out of increase in income and health consciousness among the population.

Among the large number of vegetable crops, Brinjal (Solanum melongena L.), also known 
as eggplant aubergine, or Guinea squash, is an economically important vegetable crop cultivated extensively in the tropics, subtropics and warm temperate region (Sihachakr et al., 1994). It is best suited in low to mid elevation area throughout the year in sandy loam soil with $\mathrm{pH} 5.5-6.5$.

West Bengal stands first with $23.72 \%$ share of production in India, followed by Orissa $(16.67 \%)$ and subsequently followed by Gujarat (11.67\%) (APEDA, 2014-15). West Bengal has produced 2965.60 thousand tons of brijal out of an area of 161.0 thousand ha with an average productivity of 18.42 ton/ha during the period 2012-13 (Statistical Abstract, 201213). Major brinjal producing districts in West Bengal are Nadia, 24-Parganas, Hooghly and Bardhaman. Vegetables being extremely perishable in nature, it requires speedy and efficient marketing to avoid loss in quantity and quality of the produce which sometimes force the producers to sell the output at lower prices leading to financial losses of the growers.

In the backdrop, the present study on economics of production of brinjal in Nadia District of West Bengal has been undertaken with the following specific objectives:

\section{Objectives}

To estimate the costs and returns structure of brinjal cultivation in Nadia district of West Bengal.

To assess the scope of employment generation in the cultivation of brinjal in the study area.

\section{Materials and Methods}

The study is based on the primary data collected from purposively selected Nadia district of West Bengal. A cluster of three villages belonging to purposively selected
Haringhata Block of Nadia district is taken for the study owing to higher concentration of brinjal growers. Out of the 124 brinjal farmers, a sample of 50 growers are selected following Simple Random Sampling without Replacement (SRSWOR) technique with a view to collect the necessary data related to costs and returns along with the socioeconomic information. To study the cost and margins as well as price spread associated in the marketing of brinjal, three dominant marketing channels out of a number of channels existing in the study area are considered for the present purpose. The relevant information are collected from the sample respondents in well structured schedule by personal interview method. Mainly percentage analysis and tabular method have been applied in the present study to achieve the stated objectives. To estimate the cost and returns structure of brinjal cultivation, farm management cost concepts, i.e. Cost- $\mathrm{A}_{1}, \operatorname{Cost} \mathrm{A}_{2}, \operatorname{Cost} \mathrm{B}$ and Cost $\mathrm{C}$ in their usual meaning has been applied. The data pertains to the period 2014-15.

\section{Results and Discussion}

At the outset, we will discuss the distribution of sample farmers in to various farm size groups classified based on the size of operational holdings and are presented in table 1. It reveals that the majority of farmers constituting 64 per cent of the total

From table 1 it can be observed that respondents have operational holding size less than equal to 0.5 ha with average size of 0.27 ha and farmers having holding size ranging from 0.5 to $1.0 \mathrm{ha}$ comprises 28 per cent of the total with average size of holding 0.68 ha. Only 8 per cent of total respondents belong to farm size group of greater than 1.0ha with average size accounting 1.21ha. The average size of holding is found to be $0.57 \mathrm{ha}$ when farmers belonging to all farm 
size groups are taken together. Although the average area under brinjal cultivation is estimated to be $0.12 \mathrm{ha}$ when all the sample farmers are taken together, it increases with the increase in operational holding size, i.e., the lowest area is allocated by farmers belonging to the lowest size class group of farmers accounting $0.09 \mathrm{ha}$ and it moves upward with the increase in size of holding and the maximum area measuring 0.15 ha is devoted by farmers having cultivated area greater than 1.0ha.

From table 2 it can be defined that, the cost incurred by farmers of various farm size groups towards the payment of different inputs constituting Cost $A_{1}$ is demonstrated in the table 2. It indicates that the brinjal cultivation requires on an average investment of Rs.164365.65/ha for payment of factors comprising Cost $\mathrm{A}_{1}$. The expenditure on hired human labour appears to be the most dominant cost component claiming 26.68 per cent of the total Cost $\mathrm{A}_{1}$ followed by manures and fertilizers $(20.51 \%)$ and subsequently followed by plant protection chemicals $(17.45 \%)$. Plant protection chemicals are important in the cultivation of brinjal which constituted about 20.02 per cent of the total cost (Kerutagi et al., 2000). Charges on irrigation, interest on working capital at the rate of 10 percent and land preparation come next by contributing 12.78, 9.09 and 8.70 per cent respectively arranged in descending order of their share in $\operatorname{Cost} \mathrm{A}_{1}$.

Cost $\mathrm{A}_{1}$ is found to be the highest amounting Rs.177370.56/ha for farmers having holding size lying within 0.5 to 1.0 ha due to relatively higher expenditure in absolute amount on hired human labour, irrigation and land preparation. The lowest amount of Cost $\mathrm{A}_{1}$ accounting Rs.141407.87/ha is incurred by lowest farm size group of farmers with operational holding size less than equal to 0.5 ha in which the share of hired human labour, manures and fertilizers and plant protection chemicals are estimated to be 27.55, 20.41 and 17.15 per cent respectively. Farmers belonging to the highest farm size group have spent Rs.170106.40/ha for payments towards the components constituting Cost $A_{1}$. But unlike the farmers of remaining farm size classes, they have made higher expenditures on manures and fertilizers, plant protection chemicals, irrigation and land preparation and lower hired human labour percentage terms.

From table 3 it can be observed, Cost B is estimated by adding 30 per cent of the gross return as imputed rental value of owned land to Cost $A_{1}$ as the sample farmers have not taken up brinjal cultivation in leased-in land. Table 3 discerns that the cost $\mathrm{B}$ of brinjal cultivation is calculated to be Rs.276502.12/ha on an average in which the contribution of Cost $A_{1}$ and rental value of owned land are found to be 59.44 and 40.56 per cent respectively. The behavior of Cost $\mathrm{B}$ across the farm size group is same as that of $\operatorname{Cost} \mathrm{A}_{1}$ and a definite relationship between Cost $\mathrm{B}$ and size of the holding cannot be established. The imputed rental value of owned land is observed to the highest accounting Rs.287785.65/ha for the second farm size group of farmers incurring the highest $\operatorname{Cost}_{1}$ and the lowest for the lowest farm size group of farmers amounting Rs.256112.51/ha. Cost $\mathrm{C}$, the total cost of cultivation of brinjal is obtained by adding imputed value of family labour to Cost B. It demonstrates that the brinjal requires an investment of Rs.336103.07/ha in which the share of Cost B and imputed value of family labour are worked out to be 82.27 and 17.73 per cent respectively on an average. The highest expenditure has been made by farmers having holding size 0.5 to 1.1 ha amounting Rs.353342.68/ha followed by the lowest farm size group of farmers (Rs.339239.44/ha) and subsequently by farmers belonging to the 
highest farm size class. Imputed value of value of family is recorded to be the highest accounting Rs.83126.93/ha for farmers belonging to the lowest farm size group and the lowest for the highest size class of farmers amounting Rs.56043.96/ha. Though Cost C does not follow any particular pattern across the farm size groups, but the imputed value of family labour exhibits an inverse relationship with farm size, i.e., decreases with the increase in farm size as the small farmers depends heavily on the family labour.

From table 4 it can be observed, sample farmers have realized a total return of Rs382866.62/ha on an average from a total output of $127.67 q /$ ha. The highest physical yield as well as total return is obtained by farmers with holding size lying between 0.5 to 1.0ha amounting $135.13 \mathrm{q} / \mathrm{ha}$ and Rs.397463.27/ha respectively may be due to higher investment on yield augmenting factors of production. The lowest yield as well as total return is observed in case of the highest farm size group of farmers which may be attributed to the lack of proper management and dependency on hired human labour compared the lowest farm size group of farmers who have realized more yield and return relative to the former.

Net return over various cost concepts is demonstrated in table 5. It discerns that the sample farmers have obtained a net return of Rs.218500.97, Rs.106364.50 and Rs.35108.17/ha over Coat $A_{1}$, Cost B and Cost $\mathrm{C}$ respectively on an average. Net return over Cost A1 is recorded to be the highest for the lowest farm size group of farmers mainly because of lower doses of input application including higher human labour.

Farmers with holding size 0.5 to 1.0 ha have realized the highest net return over Cost B and Cost C amounting Rs.109677.60/ and Rs.44120.59/ha respectively. Average net returns per hectare over cost $\mathrm{A}$, cost $\mathrm{B}$, cost
C1 and cost C2 was Rs. 64562, Rs. 58832, Rs. 53386 and Rs. 47526, respectively in Banaskantha, Mehsana and Sabarkantha districts of Gujarat (Patel et al., 2018).

The return-cost ratio measuring return per rupee of investment is estimated to be 2.33, 1.38 and 1.10 respectively over Coat $\mathrm{A}_{1}$, Cost $\mathrm{B}$ and Cost $\mathrm{C}$ respectively on an average (Table 6).

The return cost ratio is observed to be the highest for lowest farm size group of farmers in all measures, although they have made less expenditure and realized less total return compared to farmers belonging to farm size group with holding size ranging between 0.5 to 1.0ha may be due realisation of proportionately higher return than cost arising out of better management and heavy dependence on family labour. The benefit cost ratio for Brinjal over these cost obtained as $3.60,2.13,2.89,1.95$ and 1.77 respectively in Bandara district of Maharastra (Meshram et al., 2015).

Cultivation of brinjal provides ample opportunity for employment of both male and female workers in the rural areas. Operationwise distribution of human labour presented in table 7 reveals that the crop requires a total of 688 man-days during the complete production process of which family labour participation are recorded to be 397 man-days $(57.70 \%)$ and hired labour is engaged for 291 man-days $(42.30 \%)$. Harvesting of brinjal is appears to be the most labour consuming operation requiring an employment of 152 man-days in which the family and hired labour participation rate is found to be 58.55 and 41.45 per cent respectively. Weeding and irrigation is the second highest labour intensive operation providing an engagement of 145 man-days in which the share of family and hired labour is calculated to be 59.31 and 40.69 per cent respectively. 
Table.1 Classification of sample brinjal growers in to various farm size groups according to their operational holdings

\begin{tabular}{|c|c|c|c|}
\hline Farm size class & No. of farmers & Avg. Size of holdings & Avg. Size of holdings under brinjal \\
\hline $\mathbf{2 0 . 5}$ ha. & $32(64.00)$ & 0.27 & 0.09 \\
\hline $\mathbf{0 . 5 - 1}$ ha & $14(28.00)$ & 0.69 & 0.14 \\
\hline 1> ha & $4(8.00)$ & 1.21 & 0.15 \\
\hline Total/Average & $50(100)$ & 0.57 & 0.12 \\
\hline
\end{tabular}

Table.2 Estimation of $\operatorname{Cost}_{1}$ in brinjal cultivation by sample farmers

\begin{tabular}{|c|c|c|c|c|c|c|c|c|c|}
\hline $\begin{array}{l}\text { Farm size } \\
\text { Groups }\end{array}$ & $\begin{array}{l}\text { Planting } \\
\text { materials }\end{array}$ & $\begin{array}{c}\text { Land } \\
\text { preparation }\end{array}$ & $\begin{array}{l}\text { Hired } \\
\text { human } \\
\text { labour }\end{array}$ & $\begin{array}{l}\text { Manure } \\
\text { and } \\
\text { fertilizers }\end{array}$ & Irrigation & $\begin{array}{c}\text { plant } \\
\text { protection } \\
\text { chemicals }\end{array}$ & $\begin{array}{c}\text { Misce- } \\
\text { llaneous }\end{array}$ & $\begin{array}{c}\text { Interest } \\
\text { on } \\
\text { working } \\
\text { capital }\end{array}$ & Cost A1 \\
\hline$<0.5$ & $\begin{array}{c}5985.55 \\
(4.23)\end{array}$ & $\begin{array}{c}12280.7 \\
(8.68)\end{array}$ & $\begin{array}{c}38957.69 \\
(27.55)\end{array}$ & $\begin{array}{c}28854.49 \\
(20.41)\end{array}$ & $\begin{array}{c}18008.26 \\
(12.74)\end{array}$ & $\begin{array}{c}24251.81 \\
(17.15)\end{array}$ & $\begin{array}{l}214.11 \\
(0.15)\end{array}$ & $\begin{array}{c}12855.26 \\
(9.09)\end{array}$ & $\begin{array}{c}141407.87 \\
(100)\end{array}$ \\
\hline $0.5-1$ & $\begin{array}{c}7692.31 \\
(4.34)\end{array}$ & $\begin{array}{c}15450.93 \\
(8.71)\end{array}$ & $\begin{array}{c}48342.18 \\
(27.25)\end{array}$ & $\begin{array}{c}35862.07 \\
(20.22)\end{array}$ & $\begin{array}{c}22645.89 \\
(12.77)\end{array}$ & $\begin{array}{c}30835.54 \\
(17.38)\end{array}$ & & $\begin{array}{c}16124.59 \\
(9.09)\end{array}$ & $\begin{array}{c}177370.53 \\
(100)\end{array}$ \\
\hline 1> & $\begin{array}{c}7692.31 \\
(4.52)\end{array}$ & $\begin{array}{c}14835.16 \\
(8.72)\end{array}$ & $\begin{array}{c}41538.46 \\
(24.42)\end{array}$ & $\begin{array}{c}36923.08 \\
(21.71)\end{array}$ & $\begin{array}{c}21978.02 \\
(12.92)\end{array}$ & $\begin{array}{c}30989.01 \\
(18.21)\end{array}$ & $\begin{array}{l}686.14 \\
(0.40)\end{array}$ & $\begin{array}{c}15464.22 \\
(9.09)\end{array}$ & $\begin{array}{c}170106.40 \\
(100)\end{array}$ \\
\hline $\begin{array}{c}\text { Total/ } \\
\text { Average }\end{array}$ & $\begin{array}{c}7128.24 \\
(4.34)\end{array}$ & $\begin{array}{c}14307.64 \\
(8.70)\end{array}$ & $\begin{array}{c}44184.86 \\
(26.88)\end{array}$ & $\begin{array}{c}33710.78 \\
(20.51)\end{array}$ & $\begin{array}{c}21009.55 \\
(12.78)\end{array}$ & $\begin{array}{c}28683.49 \\
(17.45)\end{array}$ & $\begin{array}{c}398.76 \\
(0.20)\end{array}$ & $\begin{array}{c}14942.33 \\
(9.09)\end{array}$ & $\begin{array}{c}164365.65 \\
(100)\end{array}$ \\
\hline
\end{tabular}

Table.3 Estimation of cost B and cost $\mathrm{C}$ of brinjal cultivation by sample farmers

\begin{tabular}{|c|c|c|c|c|c|}
\hline $\begin{array}{c}\text { Farm size } \\
\text { groups }\end{array}$ & Cost $\mathbf{A}_{\mathbf{1}}$ & $\begin{array}{c}\text { Imputed rental value } \\
\text { of own land }\end{array}$ & Cost B & $\begin{array}{c}\text { Imputed value of } \\
\text { family labour }\end{array}$ & Cost C \\
\hline$<\mathbf{0 . 5}$ & 141407.87 & 114704.64 & 256112.51 & 83126.93 & 339239.44 \\
& $(55.21)$ & $(44.79)$ & $(100)$ & $(24.50)$ & $(100)$ \\
\hline $\mathbf{0 . 5 - 1}$ & 177370.53 & 110415.12 & 287785.65 & 65557.03 & 353342.68 \\
& $(61.63)$ & $(38.37)$ & $(100)$ & $(18.55)$ & $(100)$ \\
\hline $\mathbf{1}$ & 170106.40 & 112542.86 & 282649.26 & 56043.96 & 338693.22 \\
& $(60.18)$ & $(39.82)$ & $(100)$ & $(16.55)$ & $(100)$ \\
\hline Total/Avg. & 164365.65 & 112136.47 & 276502.12 & 59600.95 & 347758.45 \\
& $(59.44)$ & $(40.56)$ & $(100)$ & $(17.73)$ & $(100)$ \\
\hline
\end{tabular}

Table.4 Estimation of gross return from brinjal cultivation by sample farmers

\begin{tabular}{|c|c|c|c|c|}
\hline Farm size groups & Avg. size of holdings & Yield & Price & Total Return \\
\hline$<\mathbf{0 . 5}$ & 0.27 & 131.18 & 2914.69 & 382349.03 \\
\hline $\mathbf{0 . 5 - 1}$ & 0.69 & 135.13 & 2941.34 & 397463.27 \\
\hline $\mathbf{1}>$ & 1.21 & 128.33 & 2923.27 & 375143.24 \\
\hline Total/Avg. & 0.57 & 127.67 & 2926.22 & 382866.62 \\
\hline
\end{tabular}


Table.5 Estimation of net returns from brinjal by sample farmers over various cost concepts

\begin{tabular}{|c|c|c|c|c|}
\hline \multirow[t]{2}{*}{$\begin{array}{l}\text { Farm size } \\
\text { groups }\end{array}$} & \multirow[t]{2}{*}{ Gross return } & \multicolumn{3}{|c|}{$\begin{array}{l}\text { Net return over Net return on Cost B } \\
\text { Net return over Cost C }\end{array}$} \\
\hline & & Cost $A_{1}$ & Cost B & Cost C \\
\hline$<0.5$ & 382349.03 & 240941.16 & 126236.5 & 43109.59 \\
\hline $0.5-1$ & 397463.27 & 220092.74 & 109677.60 & 44120.59 \\
\hline 1> & 375143.24 & 205036.84 & 92493.98 & 36450.02 \\
\hline Total/Avg. & 382866.62 & 218500.97 & 106364.50 & 35108.17 \\
\hline
\end{tabular}

Table.6 Estimation of return-cost ratio of brinjal cultivation by sample farmers over various cost concepts

(Rs./ha)

\begin{tabular}{|c|c|c|c|}
\hline \multirow{2}{*}{$\begin{array}{c}\text { Farm size } \\
\text { groups }\end{array}$} & \multicolumn{3}{|c|}{ Return cost ratio } \\
\cline { 2 - 4 } & Cost A1 & Cost B & Cost C \\
\hline$<\mathbf{0 . 5}$ & 2.70 & 1.49 & 1.13 \\
\hline $\mathbf{0 . 5 - 1}$ & 2.24 & 1.38 & 1.12 \\
\hline $\mathbf{1}>$ & 2.21 & 1.33 & 1.11 \\
\hline Total/Av. & 2.33 & 1.38 & 1.10 \\
\hline
\end{tabular}

Table.7 Operation-wise distribution of human labour in cultivation of brinjal

\begin{tabular}{|c|c|c|c|}
\hline Operations & \multicolumn{3}{|c|}{ (Man-days /ha) } \\
\hline Ploughing & 20 & Hired labour & Total \\
& $(52.63)$ & 18 & 38 \\
& 28 & $(47.37)$ & $(5.52)$ \\
\hline Land preparation & $(50.91)$ & 27 & 55 \\
& 62 & $(49.09)$ & $(7.99)$ \\
\hline Ridge and furrow & $(62.00)$ & 38 & 100 \\
making & 55 & $(38.00)$ & $(14.53)$ \\
\hline Transplanting & $(48.67)$ & 58 & 113 \\
& 86 & $(51.32)$ & $(16.42)$ \\
\hline Weeding and & $(59.31)$ & 59 & 145 \\
irrigation & 57 & $(40.69)$ & $(21.08)$ \\
\hline Application of & $(67.06)$ & 28 & 85 \\
fertilizers and PPCL & 89 & $(32.94)$ & $(12.35)$ \\
\hline Harvesting & $(58.55)$ & 63 & 152 \\
& 397 & $(41.45)$ & $(22.09)$ \\
\hline Total/Avg. & $(57.70)$ & 291 & 688 \\
& & $(42.30)$ & $(100.00)$ \\
\hline
\end{tabular}

Transplanting and ridge and furrow making are also labour intensive operations requiring 113 and 100 man-days in which the ratio of family and hired labour are observed to be
55:58 and 62:38 respectively. In short, brinjal cultivation has generated large amount of human labour employment opportunity in the study area not only for the unemployed family 
members, but also for the unemployed rural people for earning livelihood.

Conclusion: Horticultural crops have gained tremendous importance in the domestic as well as international market arising out of increased income and health consciousness among people. Brinjal is an important vegetable crop grows extensively throughout the country. Brinjal is both a capital and labour intensive crop. It requires an investment of Rs. 164365.65/, Rs. 276502.12/ and Rs. 347758.45/ ha in terms of Cost $A_{1}$, Cost $\mathrm{B}$ and Cost $\mathrm{C}$ on an average respectively considering farmers of all size groups to realise a gross return of Rs. 382866.62/ha. The net returns are estimated to be Rs. 218500.97 , Rs. 106364.50 and Rs. 35108.17/ha over Cost $\mathrm{A}_{1}$, Cost $\mathrm{B}$ and Cost $\mathrm{C}$ with the respective return - cost ratios of 2.33,1.38 and 1.10 in the same sequence. Sample farmers belonging to farm size class ranging from 0.5 to 1.0 ha have made the highest expenditure in terms of all cost concepts, but obtained the highest return only in case of Cost C amounting Rs. 44120.59/ha. The lowest farm size group of farmers have realized the highest net revenue over Cost $\mathrm{A}_{1}$ and Cost $\mathrm{B}$ amounting Rs. 240941.16/ and Rs. 126236.50/ ha. by incurring an expenditure of Rs.141407.87/ and Rs. 256112.51/ha. Which are the lowest compared to farmers belonging to remaining farm size groups. Besides, brinjal cultivation is highly labour intensive and provides a scope for employment of 688 man-days mostly of which accounting (57.7\%) are supplied by the farm family.

\section{References}

Kertagi, M.G., Kotikal, Y.K. and Sudhindra,M (2000)Costs and returns of Brijal Production in Gokak Taluk of Belgaum District, Karnataka Journal of Agricultural Sciences, 13(2), 500-02.

Meherunnahar, M. and Paul, D.N.R. (2009) Bt Brinjal: Introducing Genetically Modified Brinjal (Eggplant/ Aubergine) in Bangladesh. Bangladesh Development Research Working Paper Series. BDRWPS no. 9, Bangladesh Development Research Centre.

Meshram, R.R., N.V. Shende and S.D. Kathale (2015) Cost Benefit Analysis and Marketing of Brinjal Vegetable in Bhandara District, Asian Resonance, 4(4), 85-92.

Patel D., Thakar K.P., Soumya C. and Modi D.B. (2018) Cost of Cultivation and marketable surplus of major Vegetables of North Gujarat, International Journal of Agriculture Sciences, 10(10), 6018-24.

\section{How to cite this article:}

Mridul Mondal, Hasrat Ali and Bimal Kumar Bera. 2019. An Economic Analysis of Brinjal (Solanum melongena L.) Cultivation in Nadia District of West Bengal, India. Int.J.Curr.Microbiol.App.Sci. 8(11): 210-216. doi: https://doi.org/10.20546/ijcmas.2019.811.026 